\title{
Nutritional and environmental studies on an ocean-going oil tanker. 2. Heat acclimatization and nutrient balances
}

\author{
K. J. COLLINS, T. P. EDDY, A. HIBBS, A. L. STOCK, \\ and E. F. WHEELER \\ MRC Environmental Physiology Unit and Department of Human Nutrition, \\ London School of Hygiene and Tropical Medicine, Keppel Street, London W.C.1, \\ the Department of Nutrition, Queen Elizabeth College, Campden Hill Road, London W.8, \\ and the Esso Petroleum Company, Esso House, Victoria Street, London S.W.1
}

Collins, K. J., Eddy, T. P., Hibbs, A., Stock, A. L., and Wheeler, E. F. (1971). Brit. J. industr. Med., 28, 246-258. Nutritional and environmental studies on an ocean-going oil tanker. 2. Heat acclimatization and nutrient balances. On the oil tanker S.S. Esso Newcastle, metabolic balances were investigated in three medical students and three working members of the crew during three-day experiments conducted when the ship was located in Biscay, the South Atlantic, and the Persian Gulf. Information was sought on the possible changes in nutrient requirements and the significance of the losses of nutrients in sweat when the subjects became acclimatized to heat. Physiological parameters of acclimatization were measured on each subject by controlled hyperthermia using a heated test-bed. Details are also given of the procedures devised for measuring the daily intake and loss of nutrients in metabolic balance studies on working subjects.

The intakes of water, sodium (including salt supplements), potassium, nitrogen, and iron provided by the ship's diet were found to be adequate, or more than adequate, during the outward voyage to the Persian Gulf. In two crew subjects who worked in the engine room, there was a trend to more positive salt and water balance with sweat losses of 3 to 4 litres per day in the Persian Gulf, but not in the three students who, though artificially acclimatized, were seldom exposed to hot working conditions. Sweat concentrations of sodium, potassium, and nitrogen were related to the rate of 24-hour sweat loss but were not altered by heat acclimatization. In the environmental and dietary conditions on board, the effect of daily sweat losses of potassium, nitrogen, and iron on the respective balances was found to be insignificant.

The urinary output of $17-\mathrm{OH}$ corticosteroids increased slightly in mid-voyage in the students but was not raised in either students or crew in the Persian Gulf. There was evidence of temporary increases in plasma cortisol accompanied by negative nitrogen and potassium balances when unacclimatized crew members were exposed to heat stress at the start of the voyage.

The investigation of human dietary requirements in hot climates has had a long, if hesitant, history. The impetus for such studies has often come from the need for more precise information on the nutritional status of service personnel in the tropics (Mitchell and Edman, 1951), and, more recently, interest in the comparative aspects has been stimulated by the International Biological Programme (Weiner, 1969). 
The subject is important to the proper rationing of men serving in hot climates, and is relevant to many industries where there is work and physiological adaptation in heat.

In hot environments, the critical need to dissipate body heat by sweating leads to additional losses of water and water-soluble nutrients such as minerals, vitamins, and nitrogen and this may alter dietary requirements. Evidence from high temperature studies suggests that nitrogen excretion is increased in severe heat stress and that appetite may diminish during heat adaptation (Collins and Weiner, 1968). The combined effect of these factors on nitrogen equilibrium may become a problem of serious concern to communities who do not enjoy a diet adequate in protein. Apart from sodium and chloride, which have previously received detailed study (Robinson and Robinson, 1954), the quantitative significance of other important sweat constituents such as nitrogen, potassium, and iron still remains a matter of debate. The contribution of nutrients in sweat to overall metabolic balance has not been unequivocally settled mainly because there are conflicting data on sweat composition determined by different methods, and in few studies has there been an attempt to measure directly total daily losses. Further exploration is also required on the question of an adaptive sweat-gland response for the conservation of these nutrients in heat acclimatization.

The present study carried out on board the oil tanker S.S. Esso Newcastle travelling from Denmark to the Persian Gulf provided an opportunity to examine some of these aspects. The influence of heat acclimatization on the relative contribution of whole body sweat losses in nutrient balances was investigated in a well-nourished working community using crew members and medical students as representative subjects. Balance studies like this impose strict demands on subjects, usually only feasible in metabolic wards, and it is largely due to the subjects' full co-operation that the authors are able to rely on the results obtained.

\section{Subjects}

The investigations reported in this paper were made on six subjects. The three medical students (A, B, P) were all aged 19 and unacclimatized to heat when the voyage started. On board they were occupied much of the time assisting with the experiments in the air-conditioned accommodation or else on deck. Of the three crew subjects, G (fireman, aged 30) and D (mechanic, aged 20) were frequently exposed to heat in the engine room during watches. The third crew subject, F (deck officer cadet, aged 20), undertook a variety of duties in all parts of the ship including the engine room. A detailed analysis of the subjects' energy intake and expenditure is given by Eddy, Stock, and Wheeler (1971).

\section{Methods}

A one-week preliminary nutritional balance study was conducted in the M.R.C. climatic chambers on the three medical students one month before departure in order to establish an experimental routine for use on board ship. During the voyage, $72-\mathrm{hr}$ nutritional balances were measured on the six subjects on three occasions, the first two in temperate ambient conditions (Biscay and South Atlantic) and the third in the Persian Gulf. Water, sodium, potassium, nitrogen, and iron balances were computed from total dietary intake and excretory losses during each 72-hr experiment. Tests of thermoregulatory function were made on each subject coincident with the balance experiments.

\section{Thermoregulatory function test}

As there was not a sufficiently stable hot climate in any of the ship's work spaces for the purpose of measuring physiological performance in heat, a controlled hyperthermia test-bed (Fox, 1967) was installed in the ship's hospital. This equipment was used to assess changes in heat acclimatization by measuring the deep body temperature at which sweating was initiated and by recording total sweat loss for a standard period of controlled hyperthermia. The subject was first washed in distilled water (the shower in the hospital was specially plumbed so that distilled water could be obtained in bulk from the ship's ample boiler supplies). After weighing on a man-balance, the subject was dressed in a polythene inner suit, dressed in the outer ventilated suit attached to the heating system of the bed, and allowed to rest comfortably for $30 \mathrm{~min}$ (air to suit $30^{\circ} \mathrm{C}$ ). Temperatures in the mouth and external auditory meati were recorded continuously using thermistors and temperature meters. After body temperature readings had reached equilibrium, the body temperature was raised at first slowly (air to suit $45^{\circ} \mathrm{C}$ ) until the temperature of sweat initiation was reached, and then rapidly (air to suit $55^{\circ} \mathrm{C}$ ) until the target body temperature of $38^{\circ} \mathrm{C}$ was attained. Hyperthermia was then maintained at $38^{\circ} \mathrm{C}$ for a further $30 \mathrm{~min}$ and during this time sweat was continuously sucked by vacuum from the inner polythene suit and collected for analysis. At the end of the experiment the subject was cooled by blowing cool air through the suit, washed with distilled water after the inner suit was removed, and finally reweighed.

Intake of nutrients During the 72 -hr balance studies arrangements were made to serve main meals to the subjects in a separate mess. The subjects were asked to name their choice from the menu before each meal so that identical duplicate portions for each subject could be weighed out before each course, one for consumption and one for sample. The duplicate sample was homogenized after removal of inedible bones, etc., and two $100-\mathrm{ml}$ aliquots were taken for analysis. Plate waste (if any) was collected, weighed, and sampled after each course. Special foods, such as ice-cream, available only in limited quantities, were sampled and analysed separately. The task of the dietitians in charge of this operation was made a little easier when the subjects agreed on a standard menu.

A record of the quantity and type of snacks (extras) taken in addition to meals was kept by each subject. 
Specimen samples of extras, which were mostly standard foods such as biscuits or sweets, were taken for analysis.

The intakes of water and cold drinks were recorded by means of marked containers. Tea and beverages were consumed from standard cups and the quantity of milk and sugar (lumps) added was also measured. Bottled and canned beverages such as beer were recorded in units of a standard volume. Analysis of all fluids taken by the subjects was obtained either by subsequent chemical analysis or by the nutrition department's computer programme (Pellett and Wheeler, 1965).

\section{Loss of nutrients}

The routine adopted in balance studies for measuring 24-hr losses from the skin involved weighing the subjects and washing the skin surface with distilled water on three occasions each day as follows:

$1000 \mathrm{hr}$ The subject was washed with a distilled-water shower and pressure spray (water at skin temperature), dried, and weighed. The subject then dressed in absorbent cotton (distilled-water washed), $T$ shirt, pants, socks, and slippers with overclothing as required. Excess sweat from the arms and face produced during the next $6 \mathrm{hr}$ was absorbed by a clean towel carried by each individual in a polythene bag.

$1600 \mathrm{hr}$ The subject undressed and the absorbent underclothing including socks (but not slippers) and hand towel were placed in a large $(142 \times 213 \mathrm{~cm})$ polythene bag. After weighing, he was then washed down by approximately 5 litres of distilled water inside the polythene bag containing underclothing. A'second towel was added to the washings after the subject had dried himself ready for reweighing. A second set of clean underclothing was then put on and the same routine was followed for the next $6 \mathrm{hr}$.

$2200 \mathrm{hr}$ The subject was washed down, dried, and weighed as before. Distilled-water washed cotton pyjamas were supplied for overnight wear and these were brought along to the hospital in a polythene bag to be added to the washings at $1000 \mathrm{hr}$ the next morning.

The Spido man-balance (accuracy $\pm 10 \mathrm{~g}$ ) had been fitted with a double pendulum movement to reduce the effects of roll and vibration on board ship. In actual fact, oscillations of the recording needle were by no means eliminated, but with practice it was found possible to duplicate readings accurately by observation of the needle and spirit level on the balance. Whole body sweat losses were thus calculated for a given period of time from body weight loss corrected for food and fluid intake, and urinary, faecal, and respiratory weight loss.

Respiratory loss of water vapour was estimated on the three students. Each subject was weighed wearing an impermeable polythene suit sealed at the neck and reweighed after resting for $2 \mathrm{hr}$ in a cool environment $\left(20^{\circ} \mathrm{C}\right)$. The loss of weight, 10 to $15 \mathrm{~g} / \mathrm{hr}$, was taken to be a reasonable approximation of respiratory water loss.

The absorbent clothing and towels added to the 5 -litre washing of the subject were spun dried and the excess fluid was returned to the polythene bag. The volume of the washing fluid was recorded and a 200-ml aliquot was taken into a polythene bottle and stored in a deep-freeze.

During the balance experiments urine collections were brought to the ship's hospital when each subject reported for weighing. The daily input of urine was thus separated into three periods, 1000 to $1600 \mathrm{hr}, 1600$ to $2200 \mathrm{hr}$, and 2200 to $1000 \mathrm{hr}$.

For faecal collections, each subject was provided with a plastic toilet seat to which a polythene bag was attached by adhesive tape. Faecal collections could thus be readily secured in the polythene bag and brought to the hospital in a plastic bucket. The samples were homogenized and an aliquot was stored in a deep-freeze. Faecal losses were precisely related to the balance period by use of the carmine marker technique. A pill containing carmine dye was taken by each subject at the start and again at the end of the 72-hr study. Faeces were collected between the time when the dye first appeared and finally disappeared in the samples.

\section{Analytical procedures}

All specimens collected during the balance experiments were kept in deep-freezes on the Esso Newcastle until the ship returned to this country. Sodium, potassium, and nitrogen were determined by AutoAnalyzer, iron in urine and sweat samples by a modification of the method described by Bothwell and Mallett (1955) and in food by the method of Wootton (1958). Control samples of the ship's distilled water and washings from clean absorbent clothing and towels were found to contain only trace quantities of these solutes.

Plasma cortisol and corticosterone concentrations were estimated in blood samples by the method of Few and Forward (Collins, Few, Forward, and Giec, 1969) and urinary $17-\mathrm{OH}$ corticosteroids in 24-hr collections by the method described by Gray, Baron, Brooks, and James (1969).

\section{Results}

\section{Acclimatization to heat}

It seemed likely that the students who lived for most of the voyage in cool ambient conditions in the accommodation would acyuire only a small degree of heat acclimatization on completion of the outward journey. After the second nutrient balance study it was decided to acclimatize them deliberately by a daily routine of work in the engine room and by exercise on deck during the 10-day voyage from South Africa to the Gulf of Oman. The students performed a routine of $10 \mathrm{~min}$ step-climbing $(16 / \mathrm{min})$ followed by $10 \mathrm{~min}$ rest for $2 \mathrm{hr}$ each day on the de-aerator cat-walk of the engine room $\left[43 \cdot 2-46 \cdot 1^{\circ} \mathrm{C}\left(110-115^{\circ} \mathrm{F}\right)\right.$ dry bulb; $28 \cdot 3-31 \cdot 6^{\circ} \mathrm{C}$ $\left(83-89^{\circ} \mathrm{F}\right)$ wet bulb]. Measurement of heart rate, body temperature, and sweat loss in the daily performance of this work indicated that the students were acclimatized to heat by the time that the third nutrient balance study was undertaken in the Persian Gulf.

The results of controlled hyperthermia thermoregulatory function tests on the six subjects during 
the three nutrient balance studies (B1, B2, B3) are summarized in Table 1 . For the students, the deep body temperature at which sweating started did not alter appreciably in tests B1 and B2 but was significantly lower in B3. Sweat loss was similar in tests B1 and B2 but greater for the same standard heat stimulus in B3. The tests confirmed the expected result, that the three students were unacclimatized to heat in B1 and B2 and acclimatized in B3.

Using the same criteria of lower body temperature for sweat initiation and increased sweat rate, crew subject $\mathrm{G}$ was unacclimatized in $\mathrm{B} 1$ and acclimatized in B2 and B3. Subject D was unacclimatized in B2 (and presumably also in B1, though it was not possible to test thermoregulatory function) and acclimatized in B3. Both of these subjects had joined the ship at Kalundborg, when the present voyage started. Subject F, on the other hand, who had served on board for a long period before this voyage, showed little change in thermoregulatory function. He was considered to have maintained the same degree of acclimatization throughout.

The results in Table 1 should not be interpreted to mean full unacclimatization or acclimatization to heat. It would in fact be necessary to undertake lengthy control experiments in order to establish absolute levels for each individual. Nevertheless, increases in sweat rate of 30 to $90 \%$ and lowering temperature of sweat onset by $0 \cdot 3$ to $0 \cdot 5^{\circ} \mathrm{C}$ suggest considerable improvement in heat acclimatization.

\section{Water balance}

It was necessary to make certain approximations in the calculation of water balance shown in Table 2 . Firstly, water gain by the oxidation of food is estimated from the total dry weight consumed, assuming that the average diet consists of a $1: 1: 5$ ratio of protein, fat, and carbohydrate and that $100 \mathrm{~g}$ of each of these foodstuffs yields 41,108 , and $55 \mathrm{~g}$ of oxidation water respectively. Alcohol provided a not insignificant part of the diet on the S.S. Esso Newcastle, and $117 \mathrm{~g}$ of water is derived from the oxidation of $100 \mathrm{~g}$ alcohol. A normal sedentary diet provides about 300 to $350 \mathrm{~g}$ metabolic water per day (Davidson and Passmore, 1969) and it is believed, therefore, that water gain under this heading is underestimated by about $100 \mathrm{~g}$. Secondly, in calculating cutaneous and respiratory weight loss from changes in total body weight, a correction needs to be applied for the difference in weight between $\mathrm{O}_{2}$ intake and $\mathrm{CO}_{2}$ output (which represents a loss of about 100 to $120 \mathrm{~g}$ /day). Overall a factor of roughly $200 \mathrm{~g}$ may be added to the final daily water balances given in Table 2. Deviations from balance amounted to 0 to $6 \%$ for the students and 0 to $7 \%$ for the crew, expressed as a percentage of daily fluid

TABLE 1

Assessment of Acclimatization to Heat by Controlled Hyperthermia (during 3-day nutrient balance studies Biscay (B1), S. Atlantic (B2), and Persian Gulf (B3) )

\begin{tabular}{|c|c|c|c|c|c|}
\hline \multirow{2}{*}{ Subject } & \multirow{2}{*}{$\begin{array}{c}\text { Nutrient } \\
\text { balance }\end{array}$} & \multicolumn{2}{|c|}{ Deep body temp. $\left({ }^{\circ} \mathrm{C}\right)$} & \multirow{2}{*}{$\begin{array}{c}\text { Total sweat } \\
\text { loss } \\
(l / h r)\end{array}$} & \multirow{2}{*}{$\begin{array}{l}\text { Sweat } \\
\text { collected } \\
(\mathrm{ml})\end{array}$} \\
\hline & & $\begin{array}{c}\text { Sweat } \\
\text { initiation }\end{array}$ & $\begin{array}{c}\text { During test } \\
\left(\text { target }=38 \cdot 0^{\circ} \mathrm{C}\right)\end{array}$ & & \\
\hline A & $\begin{array}{l}\text { B1 } \\
\text { B2 } \\
\text { B3 }\end{array}$ & $\begin{array}{l}36 \cdot 93 \\
36 \cdot 89 \\
36 \cdot 43\end{array}$ & $\begin{array}{l}38 \cdot 07 \\
38 \cdot 05 \\
37.93\end{array}$ & $\begin{array}{l}0.57 \\
0.70 \\
0.97\end{array}$ & $\begin{array}{l}270 \\
274 \\
530\end{array}$ \\
\hline B & $\begin{array}{l}\text { B1 } \\
\text { B2 } \\
\text { B3 }\end{array}$ & $\begin{array}{l}36 \cdot 72 \\
36 \cdot 69 \\
36 \cdot 46\end{array}$ & $\begin{array}{l}37 \cdot 85 \\
37 \cdot 93 \\
38 \cdot 04\end{array}$ & $\begin{array}{l}0.92 \\
0 \cdot 84 \\
1 \cdot 56\end{array}$ & $\begin{array}{l}424 \\
495 \\
750\end{array}$ \\
\hline $\mathbf{P}$ & $\begin{array}{l}\text { B1 } \\
\text { B2 } \\
\text { B3 }\end{array}$ & $\begin{array}{l}36 \cdot 81 \\
36 \cdot 93 \\
36 \cdot 68\end{array}$ & $\begin{array}{l}38 \cdot 10 \\
38 \cdot 07 \\
38 \cdot 13\end{array}$ & $\begin{array}{l}0.64 \\
0.72 \\
0.95\end{array}$ & $\begin{array}{l}255 \\
205 \\
430\end{array}$ \\
\hline G & $\begin{array}{l}\text { B1 } \\
\text { B2 } \\
\text { B3 }\end{array}$ & $\begin{array}{l}37 \cdot 48 \\
37 \cdot 00 \\
37 \cdot 09\end{array}$ & $\begin{array}{l}37 \cdot 97 \\
38 \cdot 06 \\
38 \cdot 01\end{array}$ & $\begin{array}{l}0 \cdot 86 \\
1 \cdot 00 \\
1 \cdot 09\end{array}$ & $\begin{array}{l}248 \\
536 \\
520\end{array}$ \\
\hline $\mathbf{F}$ & $\begin{array}{l}\text { B1 } \\
\text { B2 } \\
\text { B3 }\end{array}$ & $\begin{array}{l}36 \cdot 85 \\
36 \cdot 85 \\
36 \cdot 62\end{array}$ & $\begin{array}{l}37 \cdot 86 \\
38 \cdot 11 \\
37 \cdot 84\end{array}$ & $\begin{array}{l}1.03 \\
1 \cdot 04 \\
1 \cdot 11\end{array}$ & $\begin{array}{l}597 \\
600 \\
613\end{array}$ \\
\hline D & $\begin{array}{l}\text { B2 } \\
\text { B3 }\end{array}$ & $\begin{array}{l}37.53 \\
37.05\end{array}$ & $\begin{array}{l}38 \cdot 17 \\
38 \cdot 12\end{array}$ & $\begin{array}{l}0.51 \\
0.96\end{array}$ & $\begin{array}{l}233 \\
400\end{array}$ \\
\hline
\end{tabular}


TABLE 2

Mean Daily Water Balance in 72-Hr Studies

\begin{tabular}{|c|c|c|c|c|c|c|c|c|}
\hline \multirow{2}{*}{$\begin{array}{l}\text { Nutrient } \\
\text { balance }\end{array}$} & \multirow{2}{*}{ Subject } & \multicolumn{3}{|c|}{ Water intake $(g)$} & \multicolumn{3}{|c|}{ Water loss $(g)$} & \multirow{2}{*}{ Balance } \\
\hline & & Drink & Food & Oxidation & Urine & Faeces & $\begin{array}{c}\text { Cutaneous \& } \\
\text { respiratory }\end{array}$ & \\
\hline \multirow[t]{2}{*}{ B1 } & \multirow{2}{*}{$\begin{array}{l}\text { Students } \\
\text { A } \\
\text { B } \\
\text { P } \\
\quad \text { Mean }\end{array}$} & $\begin{array}{l}2358 \\
2220 \\
2583\end{array}$ & $\begin{array}{l}1239 \\
1104 \\
1092\end{array}$ & $\begin{array}{l}232 \\
229 \\
212\end{array}$ & $\begin{array}{l}1929 \\
1903 \\
2557\end{array}$ & $\begin{array}{r}52 \\
63 \\
127\end{array}$ & $\begin{array}{l}1764 \\
1884 \\
1264\end{array}$ & $\begin{array}{r}+84 \\
-237 \\
-61\end{array}$ \\
\hline & & 2387 & 1145 & 224 & 2130 & 81 & 1637 & -91 \\
\hline \multirow[t]{2}{*}{ B2 } & \multirow{2}{*}{$\begin{array}{ll}\mathbf{A} & \\
\mathrm{B} & \\
\mathbf{P} & \\
& \text { Mean }\end{array}$} & $\begin{array}{l}1707 \\
1201 \\
1814\end{array}$ & $\begin{array}{r}1075 \\
812 \\
1117\end{array}$ & $\begin{array}{l}265 \\
197 \\
259\end{array}$ & $\begin{array}{l}1617 \\
1140 \\
2213\end{array}$ & $\begin{array}{r}\overline{155} \\
81\end{array}$ & $\begin{array}{l}1534 \\
1287 \\
1100\end{array}$ & $\begin{array}{l}-104 \\
-372 \\
-204\end{array}$ \\
\hline & & 1574 & 1001 & 240 & 1657 & 79 & 1307 & -228 \\
\hline \multirow[t]{2}{*}{ B3 } & \multirow{2}{*}{$\begin{array}{ll}\mathbf{A} & \\
\mathbf{B} & \\
\mathbf{P} & \\
& \text { Mean }\end{array}$} & $\begin{array}{l}1955 \\
2215 \\
2036\end{array}$ & $\begin{array}{l}1346 \\
1035 \\
1343\end{array}$ & $\begin{array}{l}337 \\
240 \\
309\end{array}$ & $\begin{array}{l}1268 \\
1205 \\
1830\end{array}$ & $\begin{array}{r}124 \\
74 \\
57\end{array}$ & $\begin{array}{l}2330 \\
2401 \\
2215\end{array}$ & $\begin{array}{r}-84 \\
-190 \\
-414\end{array}$ \\
\hline & & 2069 & 1241 & 295 & 1434 & 85 & 2315 & -229 \\
\hline \multirow[t]{2}{*}{ B1 } & \multirow{2}{*}{$\begin{array}{l}\text { Crew } \\
\text { G } \\
\text { D } \\
\text { F } \\
\quad \text { Mean }\end{array}$} & $\begin{array}{l}3151 \\
3489 \\
3649\end{array}$ & $\begin{array}{l}807 \\
887 \\
888\end{array}$ & $\begin{array}{l}135 \\
153 \\
209\end{array}$ & $\begin{array}{l}1883 \\
1963 \\
1485\end{array}$ & $\begin{array}{r}47 \\
136 \\
129\end{array}$ & $\begin{array}{l}2631 \\
2843 \\
3687\end{array}$ & $\begin{array}{l}-468 \\
-412 \\
-555\end{array}$ \\
\hline & & 3430 & 861 & 166 & 1777 & 104 & 3054 & -478 \\
\hline \multirow[t]{2}{*}{ B2 } & \multirow{2}{*}{$\begin{array}{l}\text { G } \\
\text { D } \\
\text { F } \\
\quad \text { Mean }\end{array}$} & $\begin{array}{l}3743 \\
4112 \\
3027\end{array}$ & $\begin{array}{r}717 \\
1269 \\
985\end{array}$ & $\begin{array}{l}173 \\
286 \\
322\end{array}$ & $\begin{array}{l}2460 \\
3988 \\
1795\end{array}$ & $\begin{array}{l}120 \\
154 \\
192\end{array}$ & $\begin{array}{l}2661 \\
1659 \\
2374\end{array}$ & $\begin{array}{r}-608 \\
-134 \\
-27\end{array}$ \\
\hline & & 3627 & 990 & 260 & 2748 & 155 & 2231 & -257 \\
\hline \multirow[t]{2}{*}{ B3 } & \multirow{2}{*}{$\begin{array}{l}\text { G } \\
\text { D } \\
\text { F } \\
\quad \text { Mean }\end{array}$} & $\begin{array}{l}6024 \\
4877 \\
3712\end{array}$ & $\begin{array}{r}828 \\
1061 \\
1227\end{array}$ & $\begin{array}{l}157 \\
256 \\
337\end{array}$ & $\begin{array}{l}2957 \\
1240 \\
1393\end{array}$ & $\begin{array}{l}185 \\
108 \\
109\end{array}$ & $\begin{array}{l}3778 \\
4276 \\
4044\end{array}$ & $\begin{array}{r}+89 \\
+570 \\
-270\end{array}$ \\
\hline & & 4871 & 1039 & 250 & 1863 & 134 & 4032 & +131 \\
\hline
\end{tabular}

turnover. Daily urinary volumes were normal even in the hottest climates, indicating that the subjects achieved satisfactory water balances in all the $72-\mathrm{hr}$ studies.

In terms of the maximum feasible sweat losses (10 litres/man/day) daily sweat losses on the voyage were quite small. For the students, this was about 1 litre/day unacclimatized, and 1.5 litre/day acclimatized, assuming that there was approximately $600 \mathrm{~g} /$ day respiratory and insensible loss. Sweat losses from the three crew subjects carrying out their normal duties were higher than for the students -approximately 2 to 3 litres/day in the first balance, 1 to 2 litres/day in the second, and 3 to 4 litres/day in the third.

During the third balance study in the Persian Gulf the crew subjects lost significantly more sweat than in the previous two studies and concomitantly drank more, but, in contrast to the first two balances, the crew subjects achieved a mean positive water balance. Acclimatization to heat involves an expansion of plasma volume and extracellular fluid (Bass, Kleeman, Quinn, Henschel, and Hegnauer, 1955) and the trend to positive water balance may be a reflection of this. Although the students were also acclimatized at the time of the third balance, their turnover of water was about half that of the crew and no similar trend to more positive water balance was observed.

\section{Sodium balance}

The daily intake and loss of sodium during the three balance studies are given in Table 3 . Sources of intake include meals (from which sodium in waste 
TABLE 3

Mean Daily Sodium Balance in 72-Hr Studies

\begin{tabular}{|c|c|c|c|c|c|c|c|c|}
\hline \multirow{2}{*}{$\begin{array}{l}\text { Nutrient } \\
\text { balance }\end{array}$} & \multirow{2}{*}{ Subject } & \multicolumn{3}{|c|}{ Na intake ( $m E q)$} & \multicolumn{3}{|c|}{ Na loss $(m E q)$} & \multirow{2}{*}{ Balance } \\
\hline & & Food & Extras & Added & Urine & Faeces & Sweat & \\
\hline \multirow[t]{2}{*}{ B1 } & \multirow{2}{*}{$\begin{array}{l}\text { Students } \\
\mathrm{A} \\
\mathrm{B} \\
\mathrm{P} \\
\quad \\
\quad \text { Mean }\end{array}$} & $\begin{array}{l}177 \\
177 \\
214\end{array}$ & $\begin{array}{l}72 \\
54 \\
38\end{array}$ & $\begin{array}{l}\mathbf{0} \\
0 \\
0\end{array}$ & $\begin{array}{l}242 \\
205 \\
213\end{array}$ & $\begin{array}{l}1 \\
3 \\
5\end{array}$ & $\begin{array}{r}16 \\
13 \\
3\end{array}$ & $\begin{array}{r}-10 \\
+9 \\
+31\end{array}$ \\
\hline & & 189 & 55 & 0 & 220 & 3 & 11 & +10 \\
\hline \multirow[t]{2}{*}{ B2 } & \multirow{2}{*}{$\begin{array}{ll}\mathbf{A} & \\
\mathbf{B} & \\
\mathbf{P} & \\
& \text { Mean }\end{array}$} & $\begin{array}{l}164 \\
156 \\
178\end{array}$ & $\begin{array}{l}50 \\
64 \\
20\end{array}$ & $\begin{array}{l}0 \\
0 \\
0\end{array}$ & $\begin{array}{l}161 \\
135 \\
199\end{array}$ & $\begin{array}{l}0 \\
7 \\
3\end{array}$ & $\begin{array}{r}12 \\
16 \\
3\end{array}$ & $\begin{array}{r}+41 \\
+62 \\
-7\end{array}$ \\
\hline & & 166 & 44 & 0 & 165 & 3 & 10 & +32 \\
\hline \multirow[t]{2}{*}{ B3 } & \multirow{2}{*}{$\begin{array}{ll}\mathbf{A} & \\
\mathbf{B} & \\
\mathbf{P} & \\
& \text { Mean }\end{array}$} & $\begin{array}{l}202 \\
194 \\
226\end{array}$ & $\begin{array}{r}20 \\
17 \\
8\end{array}$ & $\begin{array}{l}17 \\
13 \\
12\end{array}$ & $\begin{array}{l}162 \\
201 \\
191\end{array}$ & $\begin{array}{l}7 \\
2 \\
4\end{array}$ & $\begin{array}{l}34 \\
32 \\
20\end{array}$ & $\begin{array}{l}+36 \\
-11 \\
+31\end{array}$ \\
\hline & & 207 & 15 & 14 & 185 & 4 & 27 & +19 \\
\hline \multirow[t]{2}{*}{ B1 } & \multirow{2}{*}{$\begin{array}{l}\text { Crew } \\
\text { G } \\
\text { D } \\
\text { F } \\
\quad \text { Mean }\end{array}$} & $\begin{array}{r}72 \\
115 \\
105\end{array}$ & $\begin{array}{l}28 \\
10 \\
41\end{array}$ & $\begin{array}{r}36 \\
54 \\
9\end{array}$ & $\begin{array}{l}92 \\
85 \\
82\end{array}$ & $\begin{array}{r}2 \\
11 \\
5\end{array}$ & $\begin{array}{l}61 \\
81 \\
14\end{array}$ & $\begin{array}{r}-19 \\
+2 \\
+54\end{array}$ \\
\hline & & 97 & 26 & 33 & 86 & 6 & 52 & +12 \\
\hline \multirow[t]{2}{*}{ B2 } & \multirow{2}{*}{$\begin{array}{l}\text { G } \\
\text { D } \\
\text { F } \\
\\
\quad \text { Mean }\end{array}$} & $\begin{array}{l}121 \\
231 \\
105\end{array}$ & $\begin{array}{r}15 \\
21 \\
140\end{array}$ & $\begin{array}{r}12 \\
24 \\
6\end{array}$ & $\begin{array}{l}130 \\
243 \\
139\end{array}$ & $\begin{array}{l}2 \\
9 \\
8\end{array}$ & $\begin{array}{l}34 \\
18 \\
16\end{array}$ & $\begin{array}{r}-18 \\
+6 \\
+88\end{array}$ \\
\hline & & 152 & 59 & 14 & 171 & 7 & 23 & +24 \\
\hline \multirow[t]{2}{*}{ B3 } & \multirow{2}{*}{$\begin{array}{l}\text { G } \\
\text { D } \\
\text { F } \\
\quad \text { Mean }\end{array}$} & $\begin{array}{l}151 \\
272 \\
122\end{array}$ & $\begin{array}{l}15 \\
23 \\
56\end{array}$ & $\begin{array}{l}92 \\
55 \\
12\end{array}$ & $\begin{array}{r}47 \\
109 \\
102\end{array}$ & $\begin{array}{l}2 \\
4 \\
4\end{array}$ & $\begin{array}{r}72 \\
117 \\
29\end{array}$ & $\begin{array}{r}+137 \\
+120 \\
+55\end{array}$ \\
\hline & & 182 & 31 & 53 & 86 & 3 & 73 & +104 \\
\hline
\end{tabular}

food is subtracted), extras (sodium in drink and snacks taken other than with meals), and added salt in the form of salt tablets $(0.3 \mathrm{~g} \mathrm{NaCl} /$ tablet $)$ or table salt taken voluntarily. The students took no additional salt in the first two studies and only a small supplement in the Persian Gulf. The crew who lost more salt in sweat took extra salt of the order of 1 to $3 \mathrm{~g}$ /day during all three balances. There were occasions, particularly in the early part of the voyage, when the sweat salt losses of the two unacclimatized crew subjects (G and D) would have tipped the scale into definite negative balance had not supplementary salt been taken.

The mean balances for both students and crew were positive in all $72 \mathrm{hr}$ experiments and more so in the third balance study on the crew subjects. A corresponding retention of sodium might be expected to accompany the trend to positive water balance if, as noted above, there was an expansion of extracellular fluid volume in acclimatization. However. it is not possible to decide whether the marked positive sodium balance was due to physiological adjustments restricting loss (Collins, 1963), to voluntary overcompensation on the part of the subjects in supplementing salt intake, or to an increase in the dietary intake of sodium.

\section{Potassium balance}

In Table 4, the mean daily potassium balances in the 72-hr studies are computed from intake (food taken at mealtimes and extras which include snacks and drinks) and output in urine, faeces, and sweat. Taking the figures as a whole, $82 \%$ of the nominal intake is lost in urine, $19 \%$ in faeces, and $10 \%$ in 
TABLE 4

Mean Daily Potassium Balance in 72-Hr Studies

\begin{tabular}{|c|c|c|c|c|c|c|c|}
\hline \multirow{2}{*}{$\begin{array}{l}\text { Nutrient } \\
\text { balance }\end{array}$} & \multirow{2}{*}{ Subject } & \multicolumn{2}{|c|}{$K$ intake $(m E q)$} & \multicolumn{3}{|c|}{$K$ loss $(m E q)$} & \multirow{2}{*}{ Balance } \\
\hline & & Food & Extras & Urine & Faeces & Sweat & \\
\hline \multirow[t]{2}{*}{ B1 } & \multirow{2}{*}{$\begin{array}{l}\text { Students } \\
\text { A } \\
\text { B } \\
\text { P } \\
\quad \text { Mean }\end{array}$} & $\begin{array}{l}65 \\
38 \\
63 \\
\end{array}$ & $\begin{array}{r}13 \\
15 \\
9\end{array}$ & $\begin{array}{l}76 \\
64 \\
69\end{array}$ & $\begin{array}{l}10 \\
19 \\
13\end{array}$ & $\begin{array}{l}6 \\
6 \\
2\end{array}$ & $\begin{array}{l}-14 \\
-36 \\
-12\end{array}$ \\
\hline & & 55 & 12 & 70 & 14 & 5 & -22 \\
\hline \multirow[t]{2}{*}{ B2 } & \multirow{2}{*}{$\begin{array}{ll}\mathbf{A} & \\
\mathbf{B} & \\
\mathbf{P} & \\
& \text { Mean }\end{array}$} & $\begin{array}{l}51 \\
59 \\
73\end{array}$ & $\begin{array}{l}6 \\
7 \\
3\end{array}$ & $\begin{array}{l}65 \\
74 \\
68\end{array}$ & $\begin{array}{l}11 \\
22 \\
17\end{array}$ & $\begin{array}{l}3 \\
4 \\
2\end{array}$ & $\begin{array}{l}-22 \\
-34 \\
-11\end{array}$ \\
\hline & & 61 & 5 & 69 & 17 & 3 & -23 \\
\hline \multirow[t]{2}{*}{ B3 } & \multirow{2}{*}{$\begin{array}{ll}\mathbf{A} & \\
\mathbf{B} & \\
\mathbf{P} & \\
& \text { Mean }\end{array}$} & $\begin{array}{l}93 \\
84 \\
92\end{array}$ & $\begin{array}{l}7 \\
7 \\
7\end{array}$ & $\begin{array}{l}58 \\
76 \\
55\end{array}$ & $\begin{array}{l}23 \\
13 \\
13\end{array}$ & $\begin{array}{l}9 \\
9 \\
8\end{array}$ & $\begin{array}{r}+10 \\
-7 \\
+23\end{array}$ \\
\hline & & 90 & 7 & 63 & 16 & 9 & +9 \\
\hline \multirow[t]{2}{*}{ B1 } & \multirow{2}{*}{$\begin{array}{l}\text { Crew } \\
\text { G } \\
\text { D } \\
\text { F } \\
\quad \text { Mean }\end{array}$} & $\begin{array}{l}27 \\
37 \\
38 \\
\end{array}$ & $\begin{array}{l}28 \\
19 \\
17\end{array}$ & $\begin{array}{l}52 \\
61 \\
37 \\
\end{array}$ & $\begin{array}{r}2 \\
14 \\
18\end{array}$ & $\begin{array}{r}8 \\
7 \\
13 \\
\end{array}$ & $\begin{array}{r}-7 \\
-26 \\
-13 \\
\end{array}$ \\
\hline & & 34 & 21 & 50 & 11 & 9 & -15 \\
\hline \multirow[t]{2}{*}{ B2 } & \multirow{2}{*}{$\begin{array}{l}\text { G } \\
\text { D } \\
\text { F } \\
\quad \text { Mean }\end{array}$} & $\begin{array}{l}44 \\
69 \\
35\end{array}$ & $\begin{array}{l}23 \\
22 \\
25\end{array}$ & $\begin{array}{l}81 \\
55 \\
56\end{array}$ & $\begin{array}{r}2 \\
19 \\
20\end{array}$ & $\begin{array}{l}7 \\
5 \\
9\end{array}$ & $\begin{array}{l}-23 \\
+12 \\
-25\end{array}$ \\
\hline & & 49 & 23 & 64 & 14 & 7 & -13 \\
\hline \multirow[t]{2}{*}{ B3 } & \multirow{2}{*}{$\begin{array}{l}\text { G } \\
\text { D } \\
\text { F } \\
\quad \text { Mean }\end{array}$} & $\begin{array}{l}45 \\
82 \\
54 \\
\end{array}$ & $\begin{array}{l}21 \\
17 \\
12 \\
\end{array}$ & $\begin{array}{l}37 \\
59 \\
49 \\
\end{array}$ & $\begin{array}{r}2 \\
18 \\
13 \\
\end{array}$ & $\begin{array}{l}10 \\
10 \\
13\end{array}$ & $\begin{array}{r}+17 \\
+12 \\
-9\end{array}$ \\
\hline & & 60 & 17 & 48 & 11 & 11 & +7 \\
\hline
\end{tabular}

sweat. For both the student and crew subjects the mean balances are slightly negative in the first two experiments and slightly positive in the last experiment. Later work has indicated that the potassium in food may have been slightly underestimated due to a high temperature of ashing and this could account for the negative balances. Tables 3 and 4 show that the increases in sodium and slight increases in potassium lost with higher sweat rates in the Persian Gulf were adequately compensated by higher intakes of both of these constituents in food. As has been pointed out by Gordon and Andrews (1966), the possibility of an imbalance between intake and output could become real when cumulative sweat losses of potassium exceeding $10 \mathrm{mEq} /$ day are combined with low intakes $(25 \mathrm{mEq} /$ day) common in rice-eating countries.

\section{Nitrogen balance}

The FAO (1965) recommended allowances (as distinct from minimum requirements) of protein (NPU 70) for the six subjects, taking into account age and weight, are 62(A), 78(B), 62(P), 60(G), 51(D), and 69(F) g per day. Protein equivalents for the mean nitrogen intakes of each subject are 127(A), 115(B), 106(P), 60(G), 90(D), and 110(F) $\mathrm{g}$ per day. Clearly this is quantitatively adequate in view of FAO recommendations, though one crew member (G) only just reached the recommended allowance.

Table 5 indicates that the subjects were generally in positive nitrogen balance throughout. The overall increase in body weight from the first to the last balance studies (mean $+2 \%$ for the students, $+0.6 \%$ for the crew) may be partly accounted for 
TABLE 5

Mean Daily Nitrogen Balance in 72-Hr Studies

\begin{tabular}{|c|c|c|c|c|c|c|c|}
\hline \multirow{2}{*}{$\begin{array}{l}\text { Nutrient } \\
\text { balance }\end{array}$} & \multirow{2}{*}{ Subject } & \multicolumn{2}{|c|}{$N$ intake $(g)$} & \multicolumn{3}{|c|}{$N$ loss $(g)$} & \multirow{2}{*}{ Balance } \\
\hline & & Food & Extras & Urine & Faeces & Sweat & \\
\hline \multirow[t]{2}{*}{ B1 } & \multirow{2}{*}{$\begin{array}{l}\text { Students } \\
\mathrm{A} \\
\mathrm{B} \\
\mathrm{P} \\
\quad \text { Mean }\end{array}$} & $\begin{array}{l}17 \cdot 3 \\
16 \cdot 9 \\
15 \cdot 0\end{array}$ & $\begin{array}{l}4 \cdot 5 \\
4 \cdot 3 \\
2 \cdot 5\end{array}$ & $\begin{array}{l}15 \cdot 1 \\
13 \cdot 5 \\
13 \cdot 6\end{array}$ & $\begin{array}{l}1 \cdot 4 \\
3 \cdot 7 \\
2 \cdot 3\end{array}$ & $\begin{array}{l}0.4 \\
0.3 \\
0.2\end{array}$ & $\begin{array}{l}+4.9 \\
+3.7 \\
+1.4\end{array}$ \\
\hline & & $16 \cdot 4$ & 3.8 & $14 \cdot 1$ & $2 \cdot 5$ & $0 \cdot 3$ & $+3 \cdot 3$ \\
\hline \multirow[t]{2}{*}{ B2 } & \multirow{2}{*}{$\begin{array}{ll}\mathbf{A} & \\
\mathbf{B} & \\
\mathbf{P} & \\
& \text { Mean } \\
\end{array}$} & $\begin{array}{l}17 \cdot 4 \\
13 \cdot 1 \\
14 \cdot 3 \\
\end{array}$ & $\begin{array}{l}2 \cdot 7 \\
4 \cdot 2 \\
1 \cdot 1 \\
\end{array}$ & $\begin{array}{l}17 \cdot 0 \\
14 \cdot 0 \\
11 \cdot 2\end{array}$ & $\begin{array}{l}1 \cdot 6 \\
2 \cdot 8 \\
2 \cdot 7\end{array}$ & $\begin{array}{l}0.3 \\
0.4 \\
0.2\end{array}$ & $\begin{array}{l}+1.2 \\
+0.1 \\
+1.3\end{array}$ \\
\hline & & $14 \cdot 9$ & $2 \cdot 7$ & $14 \cdot 1$ & $2 \cdot 4$ & 0.3 & +0.8 \\
\hline \multirow[t]{2}{*}{ B3 } & \multirow{2}{*}{$\begin{array}{ll}\mathbf{A} & \\
\mathbf{B} & \\
\mathbf{P} & \\
& \text { Mean } \\
\end{array}$} & $\begin{array}{l}17 \cdot 8 \\
15 \cdot 3 \\
17 \cdot 5\end{array}$ & $\begin{array}{l}1 \cdot 3 \\
1 \cdot 3 \\
0 \cdot 7\end{array}$ & $\begin{array}{l}14 \cdot 0 \\
11 \cdot 4 \\
13 \cdot 1\end{array}$ & $\begin{array}{l}2 \cdot 5 \\
2 \cdot 7 \\
2 \cdot 7\end{array}$ & $\begin{array}{l}0.7 \\
0.7 \\
0.5\end{array}$ & $\begin{array}{l}+1.9 \\
+1.8 \\
+1.9\end{array}$ \\
\hline & & $16 \cdot 9$ & $1 \cdot 1$ & $12 \cdot 8$ & $2 \cdot 6$ & 0.6 & +2.0 \\
\hline \multirow[t]{2}{*}{ B1 } & \multirow{2}{*}{$\begin{array}{l}\text { Crew } \\
\text { G } \\
\text { D } \\
\text { F } \\
\quad \text { Mean }\end{array}$} & $\begin{array}{r}7 \cdot 1 \\
8 \cdot 0 \\
11 \cdot 8\end{array}$ & $\begin{array}{l}2 \cdot 3 \\
1 \cdot 4 \\
3 \cdot 8\end{array}$ & $\begin{array}{l}9 \cdot 9 \\
9 \cdot 7 \\
9 \cdot 2\end{array}$ & $\begin{array}{l}1 \cdot 8 \\
2 \cdot 1 \\
2 \cdot 5\end{array}$ & $\begin{array}{l}0.4 \\
0.3 \\
0.5\end{array}$ & $\begin{array}{l}-2.7 \\
-2.7 \\
+3.4\end{array}$ \\
\hline & & $9 \cdot 0$ & $2 \cdot 5$ & $9 \cdot 6$ & $2 \cdot 1$ & 0.4 & -0.6 \\
\hline \multirow[t]{2}{*}{ B2 } & \multirow{2}{*}{$\begin{array}{ll}\text { G } & \\
\mathbf{D} & \\
\mathbf{F} & \\
& \text { Mean }\end{array}$} & $\begin{array}{r}7 \cdot 6 \\
15 \cdot 7 \\
11 \cdot 4 \\
\end{array}$ & $\begin{array}{l}2 \cdot 1 \\
2 \cdot 1 \\
9 \cdot 5 \\
\end{array}$ & $\begin{array}{r}7 \cdot 4 \\
12 \cdot 1 \\
13 \cdot 1 \\
\end{array}$ & $\begin{array}{l}2.6 \\
2.9 \\
2.4 \\
\end{array}$ & $\begin{array}{l}0.4 \\
0.3 \\
0.6 \\
\end{array}$ & $\begin{array}{r}-0.7 \\
+2.5 \\
+4.8 \\
\end{array}$ \\
\hline & & $11 \cdot 6$ & $4 \cdot 6$ & $10 \cdot 9$ & $2 \cdot 6$ & 0.4 & $+2 \cdot 3$ \\
\hline \multirow[t]{2}{*}{ B3 } & \multirow{2}{*}{$\begin{array}{l}\text { G } \\
\text { D } \\
\text { F } \\
\quad \text { Mean }\end{array}$} & $\begin{array}{r}7 \cdot 7 \\
14 \cdot 2 \\
13 \cdot 0 \\
\end{array}$ & $\begin{array}{l}2.0 \\
1.9 \\
3.5\end{array}$ & $\begin{array}{r}6.5 \\
9 \cdot 6 \\
13 \cdot 8 \\
\end{array}$ & $\begin{array}{l}2 \cdot 0 \\
2 \cdot 2 \\
1 \cdot 9\end{array}$ & $\begin{array}{l}0.4 \\
0.6 \\
0.8\end{array}$ & $\begin{array}{c}+0.8 \\
+3 \cdot 7 \\
0\end{array}$ \\
\hline & & $11 \cdot 6$ & 2.5 & $10 \cdot 0$ & $2 \cdot 0$ & 0.6 & $+1 \cdot 5$ \\
\hline
\end{tabular}

by nitrogen retention and increase in lean body mass. There is, of course, no strict relation, for changes in body fat content (mean skinfold thickness increased by $7.5 \%$ in the students but not in the crew subjects) and of body water content both contribute to the changes in body weight. Negative nitrogen balances were recorded in crew subjects G and D in B1 and in subject G in B2. In the first balance study this may have been due partly to increased nitrogen loss associated with the response to heat stress in the engine room, but in subject $\mathbf{D}$ the negative nitrogen balance may also have occurred as the result of a lower food intake at the beginning of the voyage.

Intake and loss of iron

In Table 6, the intake of iron is compared with the loss of iron in urine and sweat. Faecal iron was not estimated, but since most of the dietary iron passes through the alimentary tract unabsorbed, faecal loss can usually be considered to be nearly equal to the intake. In health, the iron content of the body remains remarkably constant and only a small proportion of the intake needs to be absorbed in order to balance the daily loss from the body. According to Davidson and Passmore (1969), the mean iron intake of the population of the United Kingdom in 1967 was $14 \mathrm{mg} / \mathrm{head} /$ day, the recommended allowance for men over 20 years being $10 \mathrm{mg} /$ day. The dietary intake on board was therefore more than adequate and higher in the students than in the crew in accord with total food intakes. Daily sweat losses of iron were computed from whole body sweat losses using the concentrations 
TABLE 6

Mean Daily Iron Intake and Losses in 72-Hr Studies

\begin{tabular}{|c|c|c|c|c|c|}
\hline \multirow{2}{*}{$\begin{array}{l}\text { Nutrient } \\
\text { balance }\end{array}$} & \multirow{2}{*}{ Subject } & \multicolumn{2}{|c|}{ Intake $(m g)$} & \multicolumn{2}{|c|}{ Losses excluding faeces $(\mathrm{mg})$} \\
\hline & & Food & Extras & Urine & Sweat \\
\hline \multirow[t]{2}{*}{ B1 } & \multirow{2}{*}{$\begin{array}{l}\text { Students } \\
\mathrm{A} \\
\mathrm{B} \\
\mathrm{P} \\
\quad \\
\quad \text { Mean }\end{array}$} & $\begin{array}{l}22 \cdot 9 \\
25 \cdot 3 \\
18 \cdot 1\end{array}$ & $\begin{array}{l}5 \cdot 9 \\
3 \cdot 9 \\
3 \cdot 3\end{array}$ & $\begin{array}{l}0.11 \\
0.09 \\
0.15\end{array}$ & $\begin{array}{l}0 \cdot 21 \\
0 \cdot 14 \\
0 \cdot 10\end{array}$ \\
\hline & & $22 \cdot 1$ & $4 \cdot 4$ & $0 \cdot 12$ & $0 \cdot 15$ \\
\hline \multirow[t]{2}{*}{ B2 } & \multirow{2}{*}{$\begin{array}{ll}\mathbf{A} & \\
\mathbf{B} & \\
\mathbf{P} & \\
& \text { Mean }\end{array}$} & $\begin{array}{l}19 \cdot 8 \\
18 \cdot 9 \\
23 \cdot 4\end{array}$ & $\begin{array}{l}3 \cdot 6 \\
3 \cdot 1 \\
1 \cdot 0\end{array}$ & $\begin{array}{l}0.09 \\
0.06 \\
0.10\end{array}$ & $\begin{array}{l}0.22 \\
0 \cdot 11 \\
0.04\end{array}$ \\
\hline & & $20 \cdot 7$ & $2 \cdot 6$ & 0.08 & $0 \cdot 12$ \\
\hline \multirow[t]{2}{*}{ B3 } & \multirow{2}{*}{$\begin{array}{ll}\mathrm{A} & \\
\mathrm{B} & \\
\mathrm{P} & \\
& \\
& \text { Mean }\end{array}$} & $\begin{array}{l}22 \cdot 8 \\
20 \cdot 6 \\
23 \cdot 9\end{array}$ & $\begin{array}{l}1.7 \\
0.7 \\
0.5\end{array}$ & $\begin{array}{l}0 \cdot 06 \\
0 \cdot 08 \\
0 \cdot 10\end{array}$ & $\begin{array}{l}0 \cdot 07 \\
0 \cdot 31 \\
0 \cdot 12\end{array}$ \\
\hline & & $22 \cdot 4$ & $1 \cdot 0$ & 0.08 & $0 \cdot 17$ \\
\hline \multirow[t]{2}{*}{ B1 } & \multirow{2}{*}{$\begin{array}{l}\text { Crew } \\
\text { G } \\
\text { D } \\
\text { F } \\
\quad \quad \quad \text { Mean }\end{array}$} & $\begin{array}{l}12 \cdot 2 \\
19 \cdot 7 \\
11 \cdot 2\end{array}$ & $\begin{array}{l}1.4 \\
1.2 \\
3.4\end{array}$ & $\begin{array}{l}0 \cdot 08 \\
0 \cdot 16 \\
0 \cdot 08\end{array}$ & $\begin{array}{c}0.42 \\
0.83\end{array}$ \\
\hline & & $14 \cdot 4$ & $2 \cdot 0$ & $0 \cdot 11$ & 0.63 \\
\hline \multirow[t]{2}{*}{ B2 } & \multirow{2}{*}{$\begin{array}{ll}\text { G } & \\
\text { D } & \\
F & \\
& \text { Mean }\end{array}$} & $\begin{array}{l}10 \cdot 3 \\
25 \cdot 3 \\
16 \cdot 4\end{array}$ & $\begin{array}{r}2 \cdot 4 \\
1 \cdot 6 \\
10 \cdot 2\end{array}$ & $\begin{array}{l}0 \cdot 12 \\
0 \cdot 19 \\
0 \cdot 10\end{array}$ & $\begin{array}{l}0 \cdot 15 \\
0 \cdot 18 \\
0 \cdot 13\end{array}$ \\
\hline & & $17 \cdot 3$ & $4 \cdot 7$ & $0 \cdot 14$ & $0 \cdot 15$ \\
\hline \multirow[t]{2}{*}{ B3 } & \multirow{2}{*}{$\begin{array}{l}\text { G } \\
\text { D } \\
\text { F } \\
\quad \text { Mean }\end{array}$} & $\begin{array}{l}14 \cdot 2 \\
20 \cdot 4 \\
15 \cdot 9\end{array}$ & $\begin{array}{l}1.4 \\
1.7 \\
4.7\end{array}$ & $\begin{array}{l}0 \cdot 16 \\
0.08 \\
0 \cdot 11\end{array}$ & $\begin{array}{l}0.46 \\
1.05 \\
0.35\end{array}$ \\
\hline & & $16 \cdot 8$ & $2 \cdot 6$ & $0 \cdot 12$ & $0 \cdot 62$ \\
\hline
\end{tabular}

measured in controlled hyperthermia experiments. In the present study, the losses of iron from the body in urine and sweat were negligible; about $0.5 \%$ of the daily intake was lost in urine (cf. Man and Wadsworth, 1969) and a little above $1 \%$ in sweat.

\section{Effect of heat acclimatization on sweat composition}

The sweat concentration of sodium, potassium, and nitrogen was measured in the six subjects using three different collection techniques during the course of one day (Table 7): (a) sweat collected by suction from the inner impermeable unit during $1 \mathrm{hr}$ controlled hyperthermia (body temperature 36.5 to $38.0^{\circ} \mathrm{C}$, conditioned air temperature 44 to $55^{\circ} \mathrm{C}$ ); (b) using the whole-body washing down procedure during $1 \mathrm{hr}$ step-climbing in the engine room (body temperature 36.5 to $38.0^{\circ} \mathrm{C}$, ambient temperature 42 to $45^{\circ} \mathrm{C}$ ); and (c) the notional sweat concentration for the remaining $22 \mathrm{hr}$ of the same day calculated from the total cutaneous losses. Though sweat rates were slightly higher in method $(a)$ as compared with $(b)(0.05<\mathbf{P}<0.02)$, sodium, potassium, and nitrogen concentrations were statistically not significantly different. With much lower sweat rates using method $(c)$, sodium concentration was significantly lower, but potassium and nitrogen did not differ from the values obtained in the $1 \mathrm{hr}$ tests.

The thermoregulatory function tests showed that five of the six subjects were relatively unacclimatized in the first balance study and acclimatized to heat in the third study. The concentrations of sodium, potassium, and nitrogen in 24-hr sweat losses for these five subjects in balance studies B1 (unac- 
TABLE 7

Sweat Composition Derived from Controlled HYPERTHERMIA AND BODY WASHING EXPERIMENTS (6 SUBJECTS \pm S.E.)

\begin{tabular}{c|c|c|c|c}
\hline Method & $\begin{array}{c}\text { Sweat rate } \\
(\text { litre/hr })\end{array}$ & $\begin{array}{c}N a \\
(m E q / l .)\end{array}$ & $\begin{array}{c}K \\
(m E q / l .)\end{array}$ & $\begin{array}{c}N \\
(m g / l .)\end{array}$ \\
\hline a & $1.103 \pm 0.10$ & $26.3 \pm 3.6$ & $3.9 \pm 0.3$ & $357 \pm 69$ \\
b & $0.815 \pm 0.06$ & $39.2 \pm 4.8$ & $4.6 \pm 0.4$ & $264 \pm 33$ \\
c & $0.069 \pm 0.18$ & $10.1 \pm 3.6$ & $4.5 \pm 0.7$ & $313 \pm 68$ \\
\hline
\end{tabular}

climatized) and B3 (acclimatized) are plotted in the Figure. The linear regressions for the unacclimatized and acclimatized data were compared after adjusting for (1) differing overall levels between subjects and (2) the correlation of solute concentration with sweat rate and were found to be not significantly different (sodium $F_{1,19}=0.21$, potassium $F_{1,19}=1 \cdot 11$, nitrogen $F_{1,19}=1 \cdot 66$ ). The variance ratio test for the comparison is thought to be valid as the tests for interaction are non-significant. The regression equations are given in the Figure. It is concluded that the levels of sodium, potassium, and nitrogen concentration in sweat are not altered by acclimatization to heat when dietary intake is adequate to balance sweat losses up to 4.0 litres/day.

Adrenal glucocorticoids

Plasma cortisol and corticosterone were determined in peripheral venous blood, obtained from the six subjects on the first and last day of each three-day balance study, and urinary 17-OH corticosteroids in 24-hr urine collections (Table 8). The blood samples were taken at the same time of day $(1000$ to $1100 \mathrm{hr}$ ); $t$ tests on paired observations for the three studies showed that there were no significant
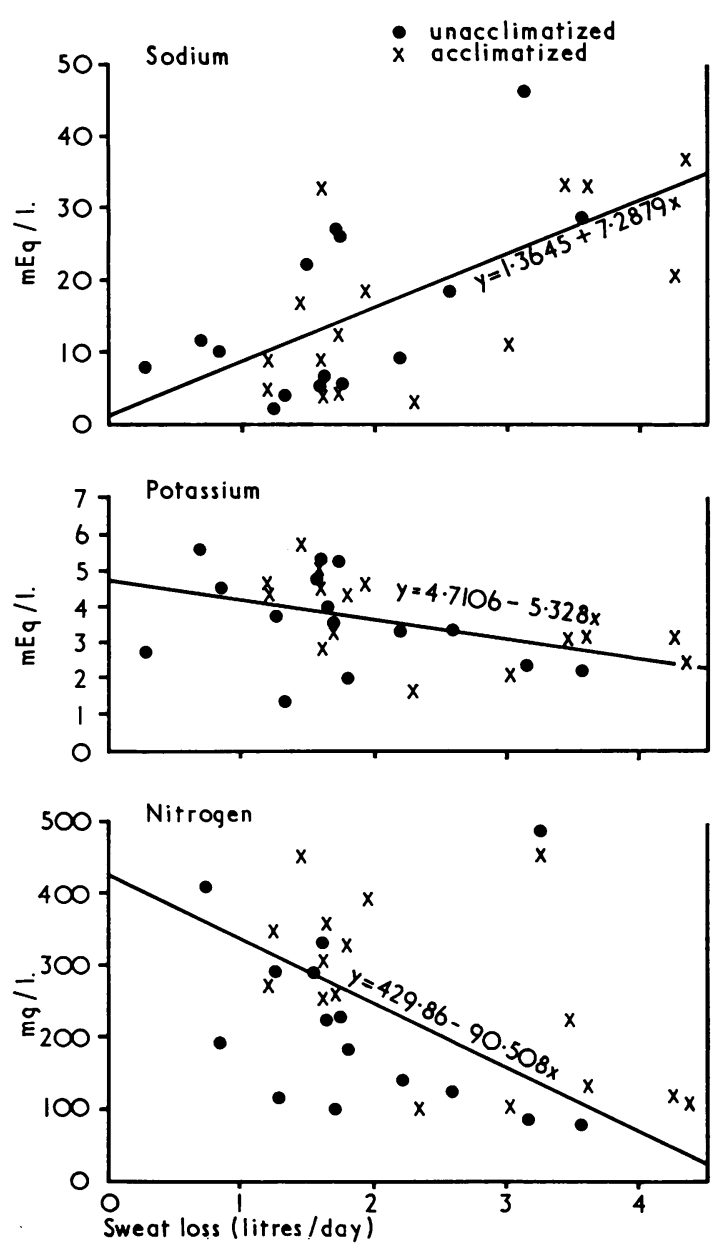

FIGURE. Relationship between sodium, potassium, and nitrogen concentrations and 24-hr sweat rates in five subjects. Regression lines fitted separately to values before and after heat acclimatization are not significantly different.

TABLE 8

Urinary and Plasma Glucocorticoids (Means for 3 Students and 3 Crew Subjects \pm S.E.)

\begin{tabular}{|c|c|c|c|c|c|c|c|c|}
\hline & \multicolumn{2}{|c|}{ Bl (Biscay) } & \multicolumn{2}{|c|}{ B2 (S. Atlantic) } & \multirow{2}{*}{\multicolumn{2}{|c|}{$\begin{array}{cc}\text { B3 } \\
\text { Crew } & \text { Persian Gulf }) \\
\text { Students }\end{array}$}} \\
\hline & & & Crew & Students & Crew & Students & & \\
\hline $\begin{array}{l}\text { Urinary 17-OHCS } \\
(\mathrm{mg} / \text { day })\end{array}$ & .. & . & $17 \cdot 6 \pm 2 \cdot 3$ & $18 \cdot 3 \pm 1 \cdot 7$ & $17 \cdot 8 \pm 1 \cdot 9$ & $23.9 \pm 1.0$ & $19 \cdot 4 \pm 0.7$ & $17 \cdot 6 \pm 2 \cdot 7$ \\
\hline $\begin{array}{l}\text { Plasma cortisol } \\
(\mu \mathrm{g} / 100 \mathrm{ml})\end{array}$ & .. & .. & $10 \cdot 4 \pm 1 \cdot 2$ & $7 \cdot 4 \pm 0 \cdot 5$ & $12 \cdot 5 \pm 1 \cdot 3$ & $7 \cdot 7 \pm 1 \cdot 0$ & $12 \cdot 6 \pm 2 \cdot 0$ & $9 \cdot 5 \pm 1 \cdot 4$ \\
\hline $\begin{array}{l}\text { Plasma corticosterone } \\
\qquad(\mu \mathrm{g} / 100 \mathrm{ml})\end{array}$ & & .. & $1 \cdot 0 \pm 0 \cdot 1$ & $0.4 \pm 0.04$ & $1 \cdot 2 \pm 0 \cdot 2$ & $0.5 \pm(0.04)$ & $0.9 \pm 0.2$ & $0.6 \pm 0.04$ \\
\hline
\end{tabular}


differences in either plasma or urinary adrenocorticosteroid levels. The normal forenoon cortisol level in most healthy subjects may be taken to be 5 to $15 \mu \mathrm{g} / 100 \mathrm{ml}$ and it is apparent that the observed levels were within this range. In the third balance study the levels for subject $G$ were 18.6 and 17.8 $\mu \mathrm{g} / 100 \mathrm{ml}$ and higher than normal. This was probably due to the fact that this subject had been on watch in stressful engine-room conditions just before sampling; for the most part the subjects had rested for 1 to $2 \mathrm{hr}$ before the blood samples were taken.

As the glucocorticoid concentration in a single sample of blood is referable to the immediately preceding events, a better indication of the overall 'stress' experienced by the subject is given by the 24-hr urinary 17-OH corticosteroids (normal range 5 to $20 \mathrm{mg} /$ day). Though there was no marked change in routine during the second balance study, the 17-OHCS levels for the three students were consistently high for this period and one can only speculate that the strain of the unaccustomed environment may have been felt more acutely in mid-voyage by these subjects rather than at the beginning or at the end. Urinary 17-OHCS output did not change in the crew.

\section{Discussion}

The specific objectives of this enquiry were to relate changes in heat acclimatization to nutrient balances and to assess the relative contribution of whole body sweat losses. That the subjects were in nutritional equilibrium during the three-day balance studies can only be assumed, but it is clear that intakes of water, sodium, potassium, nitrogen, and iron were normal or above normal and adequate to maintain positive balance. In the case of the crew subjects, an added factor is the 'stress' of working in a hot engine room, and though there was evidence of its influence on metabolic balances from day to day, the accumulated effect was apparently no greater at the end of the voyage in hot ambient conditions as judged by tests of adrenocortical activity. It is likely that this can be attributed largely to the relief afforded by airconditioned accommodation when the men were off watch (Collins, Eddy, Lee, and Swann, 1971).

In the present study, estimation of the mean 24-hr cutaneous losses for six subjects in temperate conditions were $24 \mathrm{mEq}$ sodium, $6 \mathrm{mEq}$ potassium, $0.4 \mathrm{~g}$ nitrogen, and $0.2 \mathrm{~g}$ iron (in cell-free sweat). With daily sweat output increasing to 3 to 4 litres in the Persian Gulf, the losses were $51 \mathrm{mEq}, 10 \mathrm{mEq}$, $0.6 \mathrm{~g}$, and $0.4 \mathrm{~g}$ per day respectively. Figures closely corresponding to these have also been reported by other workers (Darke, 1960; Isaksson, Lindholm, and Sjögren, 1966; Ashworth and Harrower, 1967; Vellar, 1968, 1969). In relation to intake and urinary and faecal loss the nitrogen, potassium, and iron in sweat thus appear to be very small and must bring into question the claims of Consolazio, Nelson, Matoush, Harding, and Canham (1963a) that in 7 to 8 litres of sweat there is a corresponding loss of $4 \mathrm{~g}$ or more of nitrogen which would require a 13 to $14 \%$ increase in protein intake. We find that no more than $0.8 \mathrm{~g}$ nitrogen/per day is lost in 4 litres of sweat. Further, there is a tendency for nitrogen concentration to decrease with increasing sweat rate (probably as a result of a proportionately smaller contribution from epidermal cell nitrogen) so that 7 to 8 litres/day is equivalent to only about $1.5 \mathrm{~g}$ nitrogen. In the experiments of Ashworth and Harrower (1967) acclimatized personnel were supplied with half $(50 \mathrm{~g} /$ day $)$ the protein intake of that on the Esso Newcastle. Those subjects lost $0.49 \mathrm{~g}$ nitrogen in 3 litres during $6 \frac{1}{2} \mathrm{hr}$, a figure very similar to the 24-hr cutaneous losses recorded in the present trial. Whether this level of nitrogen loss becomes important in chronic protein deficiency or whether sweat concentration is reduced with low protein intake has yet to be resolved. The discrepancy in nitrogen levels in sweat can be ascribed to the method of collection, for it is well known that the arm-bag method used by Consolazio and his colleagues is usually associated with abnormally high solute concentrations and is not representative of whole-body sweat composition (van Heyningen and Weiner, 1952).

The problem of whether the loss of iron through sweating contributes to iron-deficiency anaemia in the tropics has also given rise to much debate. The reports of Mitchell, Hamilton, and Haines (1949) and Hussain and Patwardhan (1959) that the loss of iron in sweat is of the order of $1.7 \mathrm{mg} /$ litre suggests that $10 \mathrm{mg}$ or more per day could be lost from the skin with maximum sweating. The present experiments show a much smaller content of iron in sweat collected by suction from an impermeable suit. Solute concentrations in sweat collected this way were, however, not significantly different from the whole-body method so that it was possible to deduce the daily cutaneous losses in the six subjects. A proportion of the cutaneous iron loss must originate from the shedding of desquamated epidermal cells and it is likely that this provided a significant source of iron in sweat collected by the methods of earlier workers. Even if there was a substantial loss of cell-rich sweat, which is likely to occur only in a saturated environment, the results from the present study suggest that with maximum sweating (10 litres/ day) loss of iron would not exceed $2.5 \mathrm{mg}$ and would be unlikely to give rise to iron deficiency in a healthy individual provided with a normal intake.

Thermoregulatory function tests showed that five of the six subjects were relatively more acclimatized to heat when the ship arrived in the Persian Gulf. There was no evidence to show that whole-body 
sweat concentrations of nitrogen, potassium, and iron were altered by adaptation to heat and this supports the conclusion also reached by Vellar (1969). Nor was there a reduction in sweat sodium, sometimes considered to be characteristic of the acclimatization response. Sweat salt conservation depends on mineralocorticoid activity (Collins and Weiner, 1968) stimulated by shifts in the distribution of body fluids and negative salt balance, but, with the moderate rates of sweating and generally positive salt balance in the present experiments, sodium concentration was found to be the same in both unacclimatized and acclimatized individuals.

From the calculated balances of potassium, nitrogen, and iron it appears that requirements had not altered in the five subjects who showed adaptation to heat. As may have been predicted, water and sodium balance, however, became more positive after acclimatization in two of the crew subjects. Yoshimura (1960) has reported that total body water and extracellular and intracellular fluid volumes increase in Japanese subjects with natural acclimatization in summer. MacFarlane (1963) also demonstrated that tritium space was greater in the tropics and that total body water increased by $3 \%$ of body weight in residents for each $10^{\circ}$ latitude nearer the equator, beginning at $40^{\circ}$ latitude. The two crew subjects who appeared to retain salt and water worked harder and achieved a greater fluid turnover than the students who, though acclimatized, did not increase retention of salt and water. There was, however, a lower food intake (the correlation between calorie intake and sodium intake for all subjects was +0.79 ) by the crew in balance 1 and increased salt supplementation in balance 3. But there is also an indication of sodium retention, for in spite of a $92 \%$ increase in total intake in balance 3, total 24-hr losses of sodium increased by only $6 \%$ in these two subjects.

Heat stress, particularly during extended exposure involving large sweat losses, is often accompanied by negative balances of sodium, potassium, and nitrogen (Bass et al., 1955; Streeten et al., 1960). Under such conditions, tissues may lose potassium with the breakdown of cellular protein, the loss of $1 \mathrm{~g}$ nitrogen being associated with that of approximately $2.7 \mathrm{mEq}$ potassium. It is very unlikely that the slightly negative balances of potassium in the first two balance studies on the students reflect tissue breakdown because the nitrogen balances were consistently positive. The negative balances of nitrogen and potassium in the initial studies on the crew may, on the other hand, have been related to heat stress during work in the engine room when they were relatively unacclimatized.

The authors gratefully acknowledge the help given by Dr. G. Wadsworth, Mrs. P. Henry, and Mr. A. N.
Chorlton with the biochemical analyses. A special tribute is due to the co-operative effort of our test subjects, medical students A. Attwood, A. Brain, and A. Parsons and crew members J. Gledhill, M. Dash, and T. Faithfull.

\section{References}

Ashworth, A., and Harrower, A. D. B. (1967). Protein requirements in tropical countries: nitrogen losses in sweat and their relation to nitrogen balance. Brit. $J$. Nutr., 21, 833-843.

Bass, D. E., Kleeman, C. R., Quinn, M., Henschel, A., and Hegnauer, A. H. (1955). Mechanisms of acclimatization to heat in man. Medicine (Baltimore), 34, 323-380.

Bothwell, T. H., and Mallett, B. (1955). The determination of iron in plasma or serum. Biochem. J., 59, 599-602.

Collins, K. J. (1963). Endocrine control of salt and water in hot conditions. Fed. Proc., 22, 716-720.

, Eddy, T. P., Lee, D. E., and Swann, P. G. (1971). Nutritional and environmental studies on an ocean-going oil tanker. 1. Thermal environment. Brit. J. industr. Med., 28, 237-245.

-, Few, J. D., Forward, T. J., and Giec, L. A. (1969). Stimulation of adrenal glucocorticoid secretion in man by raising the body temperature. J. Physiol. (Lond.), 202, 645-660.

- and Weiner, J. S. (1968). Endocrinological aspects of exposure to high environmental temperatures. Physiol. Rev., 48, 785-839.

Consolazio, C. F., Nelson, R. A., Matoush, L. O., Harding, R. S., and Canham, J. E. (1963a). Nitrogen excretion in sweat and its relation to nitrogen balance requirements. J. Nutr., 79, 399-406.

- Matoush, L. O., Nelson, R. A., Harding, R. S., and Canham, J. E. (1963b). Excretion of sodium, potassium, magnesium and iron in human sweat and the relation of each to balance and requirements. $J$. Nutr., 79, 407-415.

Darke, S. J. (1960). The cutaneous loss of nitrogen compounds in African adults. Brit. J. Nutr., 14, 115-119.

Davidson, S., and Passmore, R. (1969). Human Nutrition and Dietetics, 4th ed., pp. 163-171. Livingstone, Edinburgh and London.

Eddy, T. P., Stock, A. L., and Wheeler, E. F. (1971). Nutritional and environmental studies on an ocean-going oil tanker. 3. Energy balances and physique. Brit.J. industr. Med., in press.

F.A.O./W.H.O. (1965). Protein Requirements. FAO Nutrition Meetings Report, Series No. 37. Rome.

Fox, R. H. (1967). Further development of the thermoregulatory function test. In Comparative Methodology for Heat Tolerance Testing, edited by A. Henschel, pp. 267-328. U.S. Public Health Service Rpt. TR-44.

Gordon, R. S., and Andrews, H. L. (1966). Potassium depletion under heat stress. Fed. Proc., 25, 1372-1374.

Gray, C. H., Baron, D. N., Brooks, R. V., and James, V. H. T. (1969). A critical appraisal of a method of estimating urinary 17-oxosteroids and total 17-oxogenic steroids. Lancet, 1, 124-127.

Hussain, R., and Patwardhan, V. N. (1959). Iron content of thermal sweat in iron-deficiency anaemia. Lancet, 1, 1073-1074.

Isaksson, B., Lindholm, B., and Sjögren, B. (1966). Dermal losses of nutrients and their significance for human metabolic balance studies. Acta. med. scand., 179, Suppl. 445, 416-420.

MacFarlane, W. V. (1963). Endocrine functions in hot environments. In Environmental Physiology and Psychology in Arid Conditions, Reviews of Research, 22, p. 188. UNESCO, Paris. 
Man, Y. K., and Wadsworth, G. R. (1969). Urinary loss of iron and the influence on it of dietary levels of iron. Clin. Sci., 36, 479-488.

Mitchell, H. H., and Edman, M. (1951). Nutrition and Climatic Stress. Thomas, Springfield, Illinois.

—, Hamilton, T. S., and Haines, W. T. (1949). The dermal excretion under controlled environmental conditions of nitrogen and minerals in human subjects, with particular reference to calcium and iron.J. biol. Chem., 178, 345-361.

Pellett, P. L., and Wheeler, E. F. (1965). Demonstration of computer programmes applicable to nutritional calculations. Proc. Nutr. Soc., 24, xli.

Robinson, S., and Robinson, A. H. (1954). Chemical composition of sweat. Physiol. Rev., 34, 202-220.

Streeten, D. H. P., Conn, J. W., Louis, L. H., Fajans, S. S., Seltzer, H. S., Johnson, R. D., Gittler, R. D., and Dube, A. H. (1960). Secondary aldosteronism: metabolic and adrenocortical responses of normal men to high environmental temperatures. Metabolism, 9, 1071-1092. van Heyningen, R., and Weiner, J. S. (1952). A comparison of arm-bag sweat and body sweat. J. Physiol. (Lond.), 116, 395-403.

Vellar, O. D. (1968). Studies on sweat losses of nutrients. I. Iron content of whole body sweat and its association with other sweat constituents, serum iron levels, hematological indices, body surface area, and sweat rate. Scand. J. clin. Lab. Invest., 21, 157-167.

(1969). Nutrient Losses through Sweating. Institute of Hygiene, University of Oslo, Norway.

Weiner, J. S. (1969). A Guide to the Human Adaptability Proposals. I.B.P. Handbook No. 1, 2nd ed. Blackwell, Oxford.

Wootton, I. D. P. (1958). Determination of iron in biological material by spectrophotometry of ferric perchlorate. Biochem. J., 68, 197-199.

Yoshimura, H. (1960). In Essential Problems in Climatic Physiology, edited by H. Yoshimura, K. Ogata, and S. Itoh., pp. 90-101. Nankodo, Kyoto.

Received for publication August 11, 1970. 